\title{
DO BENEVOLENT AND ALTRUISTIC SUPERVISORS HAVE HIGHER POSTGRADUATE SUPERVISION THROUGHPUT? THE CONTRIBUTIONS OF INDIVIDUAL MOTIVATIONAL VALUES TO SOUTH AFRICAN POSTGRADUATE SUPERVISION THROUGHPUT
}

\section{W. Callaghan}

\author{
Management and Human Resources Management \\ University of the Witwatersrand \\ Johannesburg, South Africa \\ e-mail: chris.callaghan@wits.ac.za / https://orcid.org/0000-0002-6554-8363
}

\section{ABSTRACT}

This study seeks to understand how the individual values of a supervisor potentially influence their masters and doctoral supervision throughput. Grounded in Schwartz's theory of basic human values, the objective of the article is to test theory that predicts different effects of different value orientations on postgraduate supervision throughput, using a census sample of a large South African university. What is not clear from the literature is whether self-transcendent values (associated with benevolence and "caring" values) or self-enhancement values (associated with prioritisation of the self and achievement values) increase an individual's postgraduate supervision throughput. According to Schwartz's theory, however, self-transcendent and self-enhancement values are oppositional, in that the higher an individual's endowment is in one, the lower it is in that of the other. What is also lacking in the literature is knowledge of whether innovative openness to change values or their oppositional non-innovative conservation values enable postgraduate supervision throughput. Ordinary least squares are used to test these hypotheses across five different faculties, representing a clustering of similar academic fields. According to the results of tests across the broad faculty fields of Engineering, Commerce, Humanities, Health Sciences, and Science, it is not the individual values associated with benevolence or caring that facilitate postgraduate supervision throughput, but rather those related to the prioritisation of the self over others, such as power, achievement and hedonism. Similarly, innovation-related values associated with openness to change are largely insignificant in their associations with postgraduate supervision throughput. The implications of the findings are discussed and recommendations are derived for theory and practice.

Key words: Schwartz's theory of basic human values, higher education, motivational values, individual values, cross-cultural psychology

\section{INTRODUCTION}

The objective of this article is to test the extent to which differences in an individual's values influence an individual's postgraduate masters or doctoral supervision throughput. In so doing, 
the article contributes to a broader question related to postgraduate supervision, namely, what type of values are the majority of completing masters and doctoral degree candidates exposed to in their supervision process? Although cross-cultural differences exist across university contexts (Coldwell et al. 2016), at the individual level, individual motivational values can drive individual workplace behaviours and task outcomes (Schwartz 1992).

The concept of values is not uncontested. The notion of "values" is often shaped by different religious, cultural or political beliefs. Examples of different traditions in values research include those associated with cultural values in the culture studies tradition (Hofstede 1980), with cultural values in the psychological culture tradition (House et al. 2004), with ethics and morals (Downie 1980), with religiosity (Saroglou, Delpierre and Dernelle 2004), and with spirituality and religion (Duffy 2010), to name a few.

This study is therefore delimited to building on a specific stream of educational research that relates to Schwartz's theory of basic human values. As such, the results of this work build on a narrow stream of research, and the term "values" used here is subject to this caveat.

According to Schwartz's (1992) theory of basic human values, each individual exhibits a configuration of values that can be located on two oppositional axes. The first axis relates to the tension between self-enhancement, or self-interested and self-oriented values (such as those related to power, achievement and hedonism), which prioritise the needs and motivations of the self over those of others, and self-transcendence values (such as universalism and benevolence) which prioritise the needs and motivations of others over those of the self. The second axis captures the tension between openness to change values (such as stimulation and self-direction values) relating to an openness to new ideas and to change, and conservation values (such as security, conformity and tradition). According to this basic description, one might (naïvely) expect academic staff in a university to primarily exhibit innovative openness to change values, as the generation of new knowledge is a key academic role, as well as self-transcendence values, as they have a duty of care to students and are responsible for their development.

What is not clear from the literature is whether values that prioritise the needs of others, or caring and benevolent values, result in more effective supervision or higher student throughput in degree supervision. Similarly, it is not clear whether more "selfish" values, such as those that prioritise individual interests over those of others, are associated with higher postgraduate throughput. If the academic space is increasingly being commercialised, managerialist incentives are expected to reward productive behaviours such as throughput in postgraduate supervision.

Given the traditional nature of the university and its time-honoured traditions, the question is which of openness to change or conservation values contributes more strongly to supervision 
throughput. Is the innovativeness associated with openness to change values (Schwartz 1992) reflected in higher supervision throughput rates?

If values that prioritise the needs of the self over those of others, such as self-enhancement values of power, achievement and hedonism (Schwartz 1992), drive postgraduate supervision throughput, then further questions would arise such as the following. First, if they do, then is throughput primarily being driven by performance management systems that incentivise selfinterest? Second, if more students are being produced in a context that prioritises and rewards self-interested values, then to what extent is the majority of students going to internalise the same values and carry them forward into their practice? Although this article cannot answer these further questions, it seeks to make a contribution to the higher education literature by testing whether self-enhancement or self-transcendent values are associated with higher throughput in masters and doctoral degree supervision.

The contributions of different sets of values to supervision throughput may be particularly important in developing-country contexts such as South Africa, which require masters and doctoral graduates (skilled human capital) to solve many of their developmental challenges. In South African universities, the academic project has been placed under pressure by the recent \#FeesMustFall protests (Bitzer and De Jager 2018; Jogee, Callaghan and Callaghan 2018) and their consequences, particularly given the country's context of resource scarcity. The postgraduate supervision process has not been invulnerable to these disruptions and knowledge of how to improve supervision throughput is of particular importance in challenging contexts that may suffer similar disruptions.

The article therefore seeks to make the following main contributions to the literature. An individual's unique motivations can shape their individual values (Schwartz 1992), with important implications for their choices and preferences for different tasks in the academic work context. Lacking in the contemporary supervision literature, however, is knowledge of the contribution of an individual's value orientations to supervision throughput over time, particularly in the South African context. In developing this knowledge from empirical testing, the article contributes to this literature, offering insights into how to improve postgraduate supervision throughput.

Given the rich theoretical predictions of Schwartz theory for individual behaviour in workplace settings, this article seeks to contribute to the postgraduate supervision literature through the empirical testing of the theoretical predictions of these theoretical frameworks. Schwartz's values theory is comprehensive in that it includes include all human values, and testing their contributions to postgraduate supervision throughput may offer useful insights into the relationships between human values and supervision throughput as an academic work 
outcome.

An empirical test of values theory is therefore undertaken using data from a comprehensive purposive sampling of the academic staff of a large South African university. Checks on the representativeness of the sample suggest that the sample is reasonably representative of the underlying population.

This study may be the first in this context that investigates the values structure of individuals and how this may relate to postgraduate supervision throughput over time. As discussed, knowledge of these relationships may be particularly important in the South African context, given the resource and supervision capacity constraints that exist amidst attempts to provide more inclusive higher education. Particular attention is also paid to gender and other demographic variables that capture the effects of an individuals lived experience in this context. Implications of the findings for both postgraduate supervisors and their students are discussed and recommendations are derived.

The article proceeds as follows. Firstly, literature that relates Schwartz's values theory and its predications to postgraduate supervision throughput is reviewed. Secondly, the methodology of the study is introduced and explained. Thirdly, the results are reported and discussed. Finally, the conclusion section completes the article with a summary of the results and the conclusions of the study, together with recommendations for practice.

\section{POSTGRADUATE SUPERVISION}

In terms of current debates and trends in the postgraduate supervision literature, literature on postgraduate supervision and how to improve it in the South African context has focused on different approaches (Bitzer and Albertyn 2011) and recent work includes that on coaching (Keane 2016), the use of technology (Maor and Currie 2017; Rambe and Mkono 2019) and its different modes, such as in distance education institutions (Manyike 2017). Such work may be of particular importance, given scarce resources and the need to radically improve access to education. Indeed, under conditions of massification (Albertyn, Machika and Troskie-de Bruin 2016), the problems facing postgraduate supervision are particularly acute. This article therefore seeks to extend previous work on student-supervisor relationships (Waghid 2006; Hodza 2007), on cultural aspects of postgraduate supervision (Manidis 2016), and on the intrinsic characteristics of supervisors (Callaghan 2018) to provide empirical evidence of which individual values drive supervision throughput in this context. The contribution of this work may be particularly important in order to fully harness the postgraduate supervision opportunities offered by the new educational technologies of the Fourth Industrial Revolution (Waghid, Waghid and Waghid 2019). 
Certain debates in the literature relate to cross-disciplinary differences in postgraduate supervision. Supervisors and students typically locate research in relation to disciplinary cultures, and this phenomenon is reflected in "fields of tension" that arise in the postgraduate supervision process, which are not independent of issues of power, role expectations, and relationship dynamics in the supervisor-student relationship (Wisker and Claesson 2013).

Previous research has sought to map supervision trends in postgraduate research over time. For example, Ngulube and Ukwoma (2019) track trends in doctoral research in Library and Information Science in South African and Nigeria. They find that sole supervision predominates, and suggest that collaborative supervision should be undertaken more often, due to its benefits over dyadic supervision. In terms of these trends, Mouton (2016) argues that the production of PhDs in South Africa has been influenced by four policy discourses, relating to the need for quantity and growth in doctoral production, the need for efficiency, the need for transformation, and the need for quality. These four discourses can however be contradictory, operating in a "complex (higher education) system of recursive causality (feedback loops) and emergent properties (different levels of impact)" (Mouton 2016, 51). Mouton (2016, 52) observes that in general, "the factors are mutually reinforcing, which means that the end result is a powerful discourse of demand and accountability at every level of the system".

The complexity of the supervision system is compounded by different interdisciplinary differences. For example, those in the natural and business, economic and management sciences typically have higher progression and completion rates in honours and masters studies than do students in the humanities and social sciences (Mouton 2016).

Only 24 per cent of students at bachelor level have been found to enrol for honours level studies, and of these only 20 per cent progress to masters level, and in turn only 16 per cent of these progress to doctoral studies within five years (Mouton 2016). The South African student progression pipeline is to a large extent dependent on financial circumstances, and the competing needs of employment.

Masters study differs from doctoral studies in that doctoral studies entail more depth of scholarly engagement. Doctoral studies can be considered a "rite of passage into distinct research cultures" (Sinclair 2004, iv).

Postgraduate supervision is not a generic process, and there are distinctive differences between supervision in the sciences and the social sciences. Research in the Australian context suggests that natural scientific research culture is typically collaborative in research publication with a strong focus on obtaining external research income for research or supervision (Sinclair 2004). In contrast, humanities and arts research culture has been found to be more individualistic in publication with less of a focus on external funding, and social scientific 
research can have similarities with natural scientific and humanities and arts research, with more of a mixed culture. These differences have been found to associate with throughput rates. These cultural differences may also relate to whether a supervisor has a hands-on or hands-off approach, with the former typically being a more successful style of supervision on average (Sinclair 2004).

Despite the complexity involved in postgraduate supervision, and the challenges faced by South African academic staff, postgraduate supervision in the country seems to be relatively efficient. According to Mouton $(2016,63)$ :

"Despite high teaching loads and the increasing 'burden of supervision', academic staff at the top South African universities have increased their $\mathrm{PhD}$ output in recent years. All of this evidence suggests that South African universities and supervisors are quite efficient in the production of graduates who are in the system. Thus, university support for and supervision of doctoral students is not the major problem in the system. These structures and mechanisms are in themselves quite efficient; this is particularly evident when we focus on the throughput and completion rates of the top research universities."

Having provided an overview of certain current trends and relevant debates in the postgraduate supervision literature, theory is now reviewed and hypotheses are derived.

\section{THEORY AND HYPOTHESES}

According to Schwartz's (1994) individual values theory, values derive from biological, psychological and social motivational needs. A structure of ten value types is proposed, comprising four overarching higher order value types. This structure is dynamic - actions "taken in pursuit of each type of values have psychological, practical, and social consequences that may conflict with or may be compatible with the pursuit of other value types" (Schwartz 1996, 122).

Openness to change values comprise self-direction and stimulation values. Self-direction values reflect "independent thought and action-choosing, creating, exploring", and "creativity, freedom, [being] independent, choosing [ones] own goals and curiosity" (Schwartz and Boehnke 2004, 239). Stimulation values reflect excitement, "novelty, and challenge in life" (Schwartz and Boehnke 2004) and motivational goals are associated with daring, and the pursuit of a varied and exciting life (Schwartz 1996, 122). Insofar as curiosity and exploration are key to the academic activities associated with research and postgraduate research supervision, openness to change motivational values should be uniquely aligned with these activities, and thus the following hypothesis is proposed:

- Hypothesis A1: Openness to change values are positively and significantly associated 
with postgraduate supervision throughput.

Higher-order conservation values comprise security, conformity and tradition values, which oppose, or conflict with, openness to change values, each at opposite ends of Schwartz's (1996) circumplex (circular) structure of values. Security values relate to safety, "harmony and stability of society, of relationships, and of self", and motivational goals of reciprocity, social order, family and national security (Schwartz 1996, 221). Conformity values are associated with restraint "of actions, inclinations, and impulses likely to upset or harm others and violate social expectations or norms", and motivations of self-discipline, politeness and obedience (Schwartz 1996, 122). Tradition values reflect respect, "commitment, and acceptance of the customs and ideas that traditional culture or religion provide" and motivational goals of humility, devotion and acceptance (Schwartz 1994, 22). Because these values are inherently oppositional to the innovative attributes of openness to change values, conservation values may negatively relate to postgraduate supervision throughput, notwithstanding the conservative nature of academic formality. Hence:

- Hypothesis A2: Conservation values are negatively and significantly associated with postgraduate supervision throughput.

Self-transcendence and self-enhancement higher-order values types are also in opposition to each other. Self-enhancement values include hedonism, achievement and power values. Hedonism relates to pleasure, enjoyment of life, "and sensuous gratification for oneself" (Schwartz 1996, 122), while achievement values relate to goals of personal "success through demonstrating competence according to social standards" and being "successful, capable, ambitious and influential" (Schwartz 1996, 122). Power values are associated with motivations of "social status and prestige, control or dominance over people and resources" (Schwartz 1996, 122). If self-enhancement values prioritise the needs and motivations of the individual over others, or "selfishness" then this might not fit well with assumptions that postgraduate supervision is more productive when students are nurtured and supported, and supervisors have more caring and benevolent values. On the other hand, if work productivity is incentivised by performance management systems, more self-interested individuals may respond to these managerialist approaches, and come to dominate in postgraduate supervision throughput. Nevertheless, the following hypothesis is derived:

- Hypothesis A3: Self-enhancement values are negatively and significantly associated with postgraduate supervision throughput. 
Self-transcendence values include universalism and benevolence values. Universalism values relate to understanding, "appreciation, tolerance and protection for the welfare of all people and for nature" and with the motivational goals of "broadmindedness, wisdom, social justice, equality, a world at peace, a world of beauty, unity with nature and protection of the environment" (Schwartz 1996, 221). Benevolence values are associated with the preservation "and enhancement of the welfare of people with whom one is in frequent personal contact", and with the motivational goals of humility, devotion, respect for tradition, and moderation (Schwartz 1996, 122). To some extent, these values may also be taken to be similar to those of ubuntu, an ethic of care (Waghid and Smeyers 2012). The caring and supportive nature of these values is expected to offer a supervisor the intrinsic resources necessary for supervision throughput. Inasmuch as they are related to motivations associated with caring and support, self-transcendence values are expected to be positively related to postgraduate supervision throughput. Given that intrinsic motivations may be particularly important in research and teaching activities or related tasks (Callaghan and Coldwell 2014), those higher in benevolence values might have a motivational advantage in supervision (they might care more about their students). Hence:

- Hypothesis A4: Self-transcendence values are positively and significantly associated with postgraduate supervision throughput.

Having derived the hypotheses to be tested, the methodology of the study is now discussed.

\section{METHODOLOGY}

The study applied an exploratory cross-sectional research design, using methods that were appropriate for its objectives. The study might be considered to be located in a positivist paradigm, in that it assumes the existence of an "objective" reality, and is premised on an objective ontology and epistemology (Humphrey 2013). To the extent that it applies a deductive approach to test hypotheses, it applies the principle of falsifiability (Popper 1963), to test theory. This paradigm is appropriate for studies in the quantitative or empirical cross-cultural psychology methodologies that have applications in education research. Its advantages derive from its ability to advance scientific knowledge in that it can test theoretically derived hypotheses. The weaknesses of this paradigmatic approach lie in its inability to make inferences beyond the data that is collected. The study is also not able to develop theory, and is therefore limited to theory testing. 


\section{Sampling and data collection}

Data was collected from a large South African university using a comprehensive purposive sampling approach. All academic staff of the institution were invited to participate in the study. Principles of relevance and informed consent guided the instrument design and sampling process. Non-responses were unconditionally respected, resulting in 225 usable responses, with a response rate of about 17.3 per cent out of an approximate population size of 1300 lecturing staff. Completed questionnaires were returned using self-addressed envelopes using the university's internal mail system. A sample size calculation suggested that inferences could be made with this sample size at the 5 per cent level of inference. Ratios between demographic variables suggest that the sample was reasonably representative of the university's academic staff complement.

Certain respondents reported no supervision experience. Given that covariate effects were included to remove confounding variance, the inclusion of all respondents, regardless of supervision experience, was deemed appropriate. Further analysis was performed on the subsamples of respondents with differing postgraduate supervision experience.

Of the sub-sample of 81 respondents who report undertaking no supervision, about 78 per cent do not have doctorates, suggesting that this group consists primarily of non-doctoral and non-professorial staff, evenly split by gender. Sixty-three per cent of this subsample have memberships of professional associations. Those in this group have on average one person reporting to them, about half are married, and on average they have just less than one child.

Approximately 62 per cent of the sub-sample of 90 respondents who reported supervising only masters students are women, and 87 per cent report having professional associations. Just under half of this sub-sample report not having a doctorate. A member of this group has supervised on average just under 7 masters over their careers. Interestingly, this group has a span of control that is on average 2.26, suggesting that at least two people report to an individual. On average, a member of this group is married, with at least one dependent child.

The 53 respondents with doctoral studies supervision experience are more likely to be men (60.4\%), to report having a professional association membership, and to have on average 6.13 people reporting to them. About 68 per cent report being married, and they report having on average 1.3 children. This group has on average supervised 14.5 masters and 4 doctorates in total over their careers.

Analysis of these sub-samples was found to suggest few demographic differences between these groups except for a predominance of women in the sub-sample that have supervised only masters students, and of men in the sub-sample of those having experience of doctoral studies supervision. This gender difference persists when different sub-samples are checked. Further 
tests of the sample split by gender suggest that the average man has supervised 5.86 masters students and 1.5 doctoral students, and the average woman has supervised 6.48 masters and 0.42 doctoral students. Limiting the sample to those with doctorates, the average man has supervised 8.86 masters and 2.57 doctoral students, whereas the average woman has supervised 10.3 masters and 0.86 doctoral students. These results suggest that gender clustering might be occurring differently at masters and doctoral levels of supervision. Further research should apply qualitative methods to unearth the causes underlying these differences.

\section{Scales and measures}

Questionnaire items were used to sample self-reported numbers of completed masters and doctoral supervisions in the form of ratio data (Stevens 1946), thus meeting the requirements of equality, transitivity, additivity and the presence of a zero point (Cascio and Aguinis 2011). This number was then divided by the years of experience of an academic to obtain the dependent variable - an individual's postgraduate supervision throughput per year as an academic. It was necessary to combine masters and doctoral supervisions to obtain sufficient sample size. An individual with a preference for research or teaching may differ in their preferences for supervision, and individual satisfaction with teaching, research and administration were controlled for. These were measured by three items, broadly modelled on scale items from the Minnesota Satisfaction Questionnaire scales (Arvey et al. 1989). An example of one of the items is as follows: "most of my satisfaction in my job comes from the teaching work I do". Age was measured in years. The gender measure consisted of an item that gave a response option of either male or female. This data was captured as binary data, with male responses scored as one and female responses scored as zero. The number of dependent children of a respondent was included in order to control for potential family to work spillovers, phrased as follows: "how many dependent children do you support in your family?" A dummy variable was included to measure whether an individual was a member of at least one professional association. A measure of how many people reported to a respondent was also included, so as to control for vertical seniority or management responsibilities in the sample, given that someone with more managerial responsibility might differ from others in terms of workload. Another dummy variable was included to measure whether a respondent had English as his or her home language.

Self-reports of individual values were measured using the Schwartz Portrait Values Questionnaire (PVQ) (Schwartz 2007), which has been used in over 70 countries worldwide (Data Database 2011). These scale items have demonstrated consistent reliability, typically assessed in terms of the circumplex structure of values - following Schwartz (2007), different 
constructs were included per item and Cronbach's alpha measures were therefore not appropriate. Scale items were piloted prior to their use. Exploratory factor analysis (EFA) was used to test the discriminant validity (Campbell and Fiske 1959) of the items in relation to their circumplex structure (Kaiser-Meyer-Olkin $=0.674$; Bartletts sphericity chi-squared = 1245.577; degrees of freedom $=210 ; p<0.0001)$. The EFA loaded on seven component categories, broadly supporting correspondence with Schwartz's (2007) circumplex structure, as did a further inspection of zero-order correlations between items.

\section{Data analysis}

Data were analysed using SPSS version 23. Univariate, bivariate and multivariate analysis was used, with particular attention paid to assumptions of statistical testing. Ordinary least squares (OLS) was considered appropriate, given that endogeneity and simultaneity are less likely to be present when an outcome such as postgraduate supervision throughput is regressed on individual and cultural values. There is also less chance of reverse causality in that it is not as likely that an individual's postgraduate supervision throughput can cause their values structure, which according to Schwartz (2007) is a composite of biological, psychological and social motivational needs, or an individual's perceptions of organisational culture. In such a research project, it is important to ensure that results are not an artefact of one particular statistical test. To address this problem, 6 separate full analyses are reported in Tables 2 to 7 . These include overall tests of the contributions of values to postgraduate supervision across five faculties. Differentiating these faculties allows insights into faculty-level differences in the associations between values and supervision throughput that might differ because of differences between academic fields. Following a comprehensive process of testing allows for a more holistic analysis of these relationships.

\section{RESULTS}

Table 1 reports descriptive statistics for the sample. Abbreviations of variable names in this table are used in Tables 2 to 7. Another naïve assumption would be to expect that academic staff have values that correspond to those associated with the two adjacent Schwartz higherorder types of openness to change values associated with innovativeness, and selftranscendence, associated with caring and benevolent values. Among the highest self-reported individual values are benevolence and universalism, which support this assumption, but although self-direction is also one of the highest, stimulation is lower. Conservation values, as expected, are amongst the lowest, together with those of power. The descriptive statistics largely support the notion that academic staff have relatively high universalism and 
benevolence values that relate to caring and self-direction values that might indicate a proclivity to innovativeness. Benevolence and self-direction values also have the lowest standard deviation, suggesting that respondents differ in their responses the least with respect to these two values orientations. Across the entire sample, the average academic staff member in this context supervises about two thirds of a unit of supervision over the course of each year of experience. A unit of supervision is either a completed doctoral or a masters supervision.

Table 1: Descriptive statistics

\begin{tabular}{|c|c|c|c|c|}
\hline Variable & Mean & $\begin{array}{l}\text { Standard } \\
\text { deviation }\end{array}$ & Minimum & Maximum \\
\hline superv (postgraduate supervision throughput) & 0.66 & 1.10 & 0 & 8.25 \\
\hline SatTeach (satisfaction with teaching) & 4.24 & 1.58 & 1 & 7 \\
\hline SatAdmin (satisfaction with administration) & 2.23 & 1.53 & 1 & 7 \\
\hline SatRes (satisfaction with research) & 4.87 & 1.55 & 1 & 7 \\
\hline Age & 40.67 & 10.55 & 22 & 72 \\
\hline Gender (binary variable $1=$ male) & 0.47 & 0.50 & 0 & 1 \\
\hline Prof assoc (membership of professional association) & 0.81 & 0.39 & 0 & 1 \\
\hline Span control (number of people reporting to an individual) & 2.70 & 6.45 & 0 & 47 \\
\hline Dependents (number of dependent children) & 1.09 & 1.28 & 0 & 7 \\
\hline English (English as a home language) & 0.52 & 0.50 & 0 & 1 \\
\hline SelfDirection & 10.36 & 1.45 & 4 & 12 \\
\hline Power & 6.75 & 2.07 & 2 & 12 \\
\hline Universalism & 14.97 & 2.19 & 8 & 18 \\
\hline Achievement & 8.68 & 2.17 & 2 & 12 \\
\hline Security & 8.74 & 2.42 & 2 & 12 \\
\hline Stimulation & 8.15 & 2.32 & 3 & 12 \\
\hline Conformity & 7.05 & 2.35 & 2 & 12 \\
\hline Tradition & 7.78 & 2.22 & 2 & 12 \\
\hline Hedonism & 7.34 & 2.54 & 2 & 12 \\
\hline Benevolence & 9.63 & 1.55 & 5 & 12 \\
\hline
\end{tabular}

Tables 2 to 7 report the tests of associations between perceptions of each of the Schwartz values dimensions and postgraduate supervision throughput. The Schwartz values represent selfreports of an individual's own values. 
Table 2: Entire sample: Schwartz's values and postgraduate supervision productivity

\begin{tabular}{|c|c|c|c|c|c|c|c|c|c|c|c|}
\hline & (1) & (2) & (3) & (4) & (5) & (6) & (7) & (8) & (9) & (10) & (11) \\
\hline Factors & superv & superv & superv & Superv & superv & superv & superv & superv & superv & superv & superv \\
\hline SatTeach & $\begin{array}{l}-0.027 \\
(0.053)\end{array}$ & $\begin{array}{l}-0.035 \\
(0.050)\end{array}$ & $\begin{array}{l}-0.031 \\
(0.056)\end{array}$ & $\begin{array}{l}-0.034 \\
(0.053)\end{array}$ & $\begin{array}{l}-0.030 \\
(0.050)\end{array}$ & $\begin{array}{l}-0.028 \\
(0.053)\end{array}$ & $\begin{array}{l}-0.033 \\
(0.059)\end{array}$ & $\begin{array}{l}-0.030 \\
(0.049)\end{array}$ & $\begin{array}{l}-0.030 \\
(0.042)\end{array}$ & $\begin{array}{l}-0.038 \\
(0.042)\end{array}$ & $\begin{array}{l}-0.021 \\
(0.040)\end{array}$ \\
\hline SatAdmin & $\begin{array}{l}-0.055 \\
(0.031)\end{array}$ & $\begin{array}{l}-0.074^{*} \\
(0.029)\end{array}$ & $\begin{array}{c}-0.054 \\
(0.029)\end{array}$ & $\begin{array}{l}-0.059 \\
(0.034)\end{array}$ & $\begin{array}{c}-0.052 \\
(0.033)\end{array}$ & $\begin{array}{l}-0.045 \\
(0.028)\end{array}$ & $\begin{array}{c}-0.052 \\
(0.027)\end{array}$ & $\begin{array}{l}-0.042^{*} \\
(0.019)\end{array}$ & $\begin{array}{l}-0.054 \\
(0.043)\end{array}$ & $\begin{array}{c}-0.062 \\
(0.043)\end{array}$ & $\begin{array}{l}-0.052 \\
(0.043)\end{array}$ \\
\hline SatRes & $\begin{array}{c}0.002 \\
(0.043)\end{array}$ & $\begin{array}{c}0.014 \\
(0.046)\end{array}$ & $\begin{array}{c}0.004 \\
(0.040)\end{array}$ & $\begin{array}{c}0.009 \\
(0.041)\end{array}$ & $\begin{array}{c}0.006 \\
(0.044)\end{array}$ & $\begin{array}{c}0.020 \\
(0.051)\end{array}$ & $\begin{array}{c}0.003 \\
(0.038)\end{array}$ & $\begin{array}{c}0.004 \\
(0.041)\end{array}$ & $\begin{array}{c}0.002 \\
(0.054)\end{array}$ & $\begin{array}{c}0.006 \\
(0.054)\end{array}$ & $\begin{array}{c}0.004 \\
(0.055)\end{array}$ \\
\hline Age & $\begin{array}{c}0.008 \\
(0.005)\end{array}$ & $\begin{array}{c}0.010 \\
(0.006)\end{array}$ & $\begin{array}{c}0.007 \\
(0.006)\end{array}$ & $\begin{array}{c}0.009 \\
(0.006)\end{array}$ & $\begin{array}{c}0.007 \\
(0.006)\end{array}$ & $\begin{array}{c}0.007 \\
(0.006)\end{array}$ & $\begin{array}{c}0.010 \\
(0.005)\end{array}$ & $\begin{array}{c}0.007 \\
(0.005)\end{array}$ & $\begin{array}{c}0.006 \\
(0.007)\end{array}$ & $\begin{array}{c}0.011 \\
(0.007)\end{array}$ & $\begin{array}{c}0.007 \\
(0.006)\end{array}$ \\
\hline Gender1male & $\begin{array}{l}-0.068 \\
(0.183)\end{array}$ & $\begin{array}{l}-0.060 \\
(0.203)\end{array}$ & $\begin{array}{l}-0.054 \\
(0.179)\end{array}$ & $\begin{array}{l}-0.050 \\
(0.193)\end{array}$ & $\begin{array}{l}-0.073 \\
(0.193)\end{array}$ & $\begin{array}{l}-0.047 \\
(0.175)\end{array}$ & $\begin{array}{l}-0.069 \\
(0.180)\end{array}$ & $\begin{array}{l}-0.067 \\
(0.179)\end{array}$ & $\begin{array}{l}-0.062 \\
(0.154)\end{array}$ & $\begin{array}{l}-0.071 \\
(0.153)\end{array}$ & $\begin{array}{l}-0.081 \\
(0.158)\end{array}$ \\
\hline Prof assoc & $\begin{array}{c}0.135 \\
(0.149)\end{array}$ & $\begin{array}{c}0.146 \\
(0.180)\end{array}$ & $\begin{array}{c}0.136 \\
(0.150)\end{array}$ & $\begin{array}{c}0.129 \\
(0.180)\end{array}$ & $\begin{array}{c}0.131 \\
(0.143)\end{array}$ & $\begin{array}{c}0.090 \\
(0.113)\end{array}$ & $\begin{array}{c}0.129 \\
(0.160)\end{array}$ & $\begin{array}{c}0.144 \\
(0.161)\end{array}$ & $\begin{array}{c}0.148 \\
(0.241)\end{array}$ & $\begin{array}{c}0.128 \\
(0.235)\end{array}$ & $\begin{array}{c}0.150 \\
(0.240)\end{array}$ \\
\hline $\begin{array}{l}\text { Span } \\
\text { control }\end{array}$ & $\begin{array}{l}0.031^{*} \\
(0.012)\end{array}$ & $\begin{array}{l}0.031^{*} \\
(0.012)\end{array}$ & $\begin{array}{l}0.032^{* *} \\
(0.011)\end{array}$ & $\begin{array}{l}0.031^{*} \\
(0.012)\end{array}$ & $\begin{array}{l}0.032^{*} \\
(0.012)\end{array}$ & $\begin{array}{l}0.033^{*} \\
(0.012)\end{array}$ & $\begin{array}{l}0.031^{*} \\
(0.011)\end{array}$ & $\begin{array}{l}0.032^{* *} \\
(0.010)\end{array}$ & $\begin{array}{l}0.032^{*} \\
(0.017)\end{array}$ & $\begin{array}{l}0.032^{*} \\
(0.017)\end{array}$ & $\begin{array}{l}0.030^{*} \\
(0.017)\end{array}$ \\
\hline Dependents & $\begin{array}{c}0.037 \\
(0.040)\end{array}$ & $\begin{array}{c}0.027 \\
(0.044)\end{array}$ & $\begin{array}{c}0.033 \\
(0.042)\end{array}$ & $\begin{array}{c}0.030 \\
(0.043)\end{array}$ & $\begin{array}{c}0.037 \\
(0.040)\end{array}$ & $\begin{array}{c}0.041 \\
(0.039)\end{array}$ & $\begin{array}{c}0.043 \\
(0.034)\end{array}$ & $\begin{array}{c}0.050 \\
(0.026)\end{array}$ & $\begin{array}{c}0.047 \\
(0.061)\end{array}$ & $\begin{array}{c}0.036 \\
(0.064)\end{array}$ & $\begin{array}{c}0.033 \\
(0.066)\end{array}$ \\
\hline English & $\begin{array}{c}0.159 \\
(0.120)\end{array}$ & $\begin{array}{c}0.146 \\
(0.138)\end{array}$ & $\begin{array}{c}0.156 \\
(0.122)\end{array}$ & $\begin{array}{c}0.140 \\
(0.135)\end{array}$ & $\begin{array}{c}0.145 \\
(0.124)\end{array}$ & $\begin{array}{c}0.120 \\
(0.136)\end{array}$ & $\begin{array}{c}0.161 \\
(0.130)\end{array}$ & $\begin{array}{c}0.120 \\
(0.150)\end{array}$ & $\begin{array}{c}0.149 \\
(0.136)\end{array}$ & $\begin{array}{c}0.170 \\
(0.137)\end{array}$ & $\begin{array}{c}0.152 \\
(0.137)\end{array}$ \\
\hline SelfDirection & $\begin{array}{c}0.047 \\
(0.036)\end{array}$ & & & & & & & & & & \\
\hline Power & & $\begin{array}{l}0.075^{\star *} \\
(0.024)\end{array}$ & & & & & & & & & \\
\hline Universalism & & & $\begin{array}{c}0.026 \\
(0.035)\end{array}$ & & & & & & & & \\
\hline Achievement & & & & $\begin{array}{l}0.048^{*} \\
(0.021)\end{array}$ & & & & & & & \\
\hline Security & & & & & $\begin{array}{l}-0.012 \\
(0.040)\end{array}$ & & & & & & \\
\hline Performance & & & & & & $\begin{array}{c}-0.022 \\
(0.021)\end{array}$ & & & & & \\
\hline Stimulation & & & & & & & $\begin{array}{c}0.041 \\
(0.040)\end{array}$ & & & & \\
\hline Conformity & & & & & & & & $\begin{array}{l}-0.045 \\
(0.055)\end{array}$ & & & \\
\hline Tradition & & & & & & & & & $\begin{array}{c}-0.029 \\
(0.024)\end{array}$ & & \\
\hline Hedonism & & & & & & & & & & $\begin{array}{l}0.049^{*} \\
(0.028)\end{array}$ & \\
\hline Benevolence & & & & & & & & & & & $\begin{array}{l}-0.059 \\
(0.060)\end{array}$ \\
\hline Constant & $\begin{array}{l}-0.230 \\
(0.144)\end{array}$ & $\begin{array}{l}-0.285 \\
(0.292)\end{array}$ & $\begin{array}{l}-0.078 \\
(0.748)\end{array}$ & $\begin{array}{l}-0.171 \\
(0.260)\end{array}$ & $\begin{array}{c}0.403 \\
(0.292)\end{array}$ & $\begin{array}{c}0.538 \\
(0.315)\end{array}$ & $\begin{array}{l}-0.116 \\
(0.293)\end{array}$ & $\begin{array}{c}0.595 \\
(0.404)\end{array}$ & $\begin{array}{c}0.552 \\
(0.551)\end{array}$ & $\begin{array}{l}-0.151 \\
(0.552)\end{array}$ & $\begin{array}{c}0.833 \\
(0.726)\end{array}$ \\
\hline Observations & 222 & 222 & 222 & 222 & 222 & 222 & 222 & 222 & 221 & 222 & 222 \\
\hline R-squared & 0.073 & 0.088 & 0.072 & 0.078 & 0.070 & 0.076 & 0.076 & 0.078 & 0.073 & 0.081 & 0.076 \\
\hline
\end{tabular}


Table 3: Engineering and Built Environment: Schwartz's values and postgraduate supervision productivity

\begin{tabular}{|c|c|c|c|c|c|c|c|c|c|c|c|}
\hline & (1) & (2) & (3) & (4) & (5) & (6) & (7) & (8) & (9) & (10) & (11) \\
\hline ractors & superv & superv & superv & superv & superv & superv & superv & superv & superv & superv & superv \\
\hline SatTeach & $\begin{array}{c}0.111 \\
(0.284)\end{array}$ & $\begin{array}{c}0.063 \\
(0.323)\end{array}$ & $\begin{array}{c}0.128 \\
(0.324)\end{array}$ & $\begin{array}{c}0.179 \\
(0.275)\end{array}$ & $\begin{array}{c}0.163 \\
(0.320)\end{array}$ & $\begin{array}{c}0.147 \\
(0.261)\end{array}$ & $\begin{array}{c}0.079 \\
(0.274)\end{array}$ & $\begin{array}{l}-0.021 \\
(0.246)\end{array}$ & $\begin{array}{c}0.032 \\
(0.294)\end{array}$ & $\begin{array}{c}0.065 \\
(0.293)\end{array}$ & $\begin{array}{c}0.143 \\
(0.305)\end{array}$ \\
\hline SatAdmin & $\begin{array}{l}-0.548 \\
(0.375)\end{array}$ & $\begin{array}{l}-0.473 \\
(0.335)\end{array}$ & $\begin{array}{l}-0.523 \\
(0.387)\end{array}$ & $\begin{array}{c}-0.619^{*} \\
(0.320)\end{array}$ & $\begin{array}{l}-0.555 \\
(0.376)\end{array}$ & $\begin{array}{l}-0.300 \\
(0.269)\end{array}$ & $\begin{array}{l}-0.158 \\
(0.263)\end{array}$ & $\begin{array}{l}-0.537 \\
(0.335)\end{array}$ & $\begin{array}{l}-0.556 \\
(0.372)\end{array}$ & $\begin{array}{l}-0.479 \\
(0.343)\end{array}$ & $\begin{array}{l}-0.503 \\
(0.367)\end{array}$ \\
\hline SatRes & $\begin{array}{l}-0.006 \\
(0.224)\end{array}$ & $\begin{array}{c}0.060 \\
(0.241)\end{array}$ & $\begin{array}{c}0.025 \\
(0.231)\end{array}$ & $\begin{array}{c}0.209 \\
(0.250)\end{array}$ & $\begin{array}{c}0.060 \\
(0.217)\end{array}$ & $\begin{array}{c}0.047 \\
(0.231)\end{array}$ & $\begin{array}{c}0.038 \\
(0.193)\end{array}$ & $\begin{array}{l}-0.022 \\
(0.175)\end{array}$ & $\begin{array}{l}-0.189 \\
(0.266)\end{array}$ & $\begin{array}{c}0.025 \\
(0.222)\end{array}$ & $\begin{array}{c}0.071 \\
(0.253)\end{array}$ \\
\hline Age & $\begin{array}{c}0.033 \\
(0.045)\end{array}$ & $\begin{array}{c}0.054 \\
(0.047)\end{array}$ & $\begin{array}{c}0.038 \\
(0.049)\end{array}$ & $\begin{array}{c}0.069 \\
(0.047)\end{array}$ & $\begin{array}{c}0.040 \\
(0.050)\end{array}$ & $\begin{array}{c}0.017 \\
(0.046)\end{array}$ & $\begin{array}{c}0.034 \\
(0.034)\end{array}$ & $\begin{array}{c}0.064 \\
(0.058)\end{array}$ & $\begin{array}{c}0.039 \\
(0.054)\end{array}$ & $\begin{array}{c}0.041 \\
(0.041)\end{array}$ & $\begin{array}{c}0.029 \\
(0.047)\end{array}$ \\
\hline Gender1male & $\begin{array}{c}1.177 \\
(1.470)\end{array}$ & $\begin{array}{c}0.843 \\
(1.384)\end{array}$ & $\begin{array}{c}1.070 \\
(1.532)\end{array}$ & $\begin{array}{c}1.024 \\
(1.153)\end{array}$ & $\begin{array}{c}1.050 \\
(1.492)\end{array}$ & $\begin{array}{c}0.725 \\
(1.165)\end{array}$ & $\begin{array}{l}-0.007 \\
(1.225)\end{array}$ & $\begin{array}{c}1.722 \\
(1.076)\end{array}$ & $\begin{array}{c}2.467 \\
(1.987)\end{array}$ & $\begin{array}{c}0.771 \\
(1.477)\end{array}$ & $\begin{array}{c}0.892 \\
(1.406)\end{array}$ \\
\hline Span control & $\begin{array}{c}0.047 \\
(0.176)\end{array}$ & $\begin{array}{c}0.027 \\
(0.158)\end{array}$ & $\begin{array}{c}0.044 \\
(0.184)\end{array}$ & $\begin{array}{l}-0.004 \\
(0.152)\end{array}$ & $\begin{array}{c}0.061 \\
(0.149)\end{array}$ & $\begin{array}{l}-0.056 \\
(0.147)\end{array}$ & $\begin{array}{l}-0.069 \\
(0.136)\end{array}$ & $\begin{array}{l}-0.086 \\
(0.144)\end{array}$ & $\begin{array}{l}-0.045 \\
(0.152)\end{array}$ & $\begin{array}{c}0.070 \\
(0.171)\end{array}$ & $\begin{array}{c}0.054 \\
(0.178)\end{array}$ \\
\hline Dependents & $\begin{array}{l}-0.438 \\
(0.390)\end{array}$ & $\begin{array}{l}-0.377 \\
(0.389)\end{array}$ & $\begin{array}{l}-0.376 \\
(0.450)\end{array}$ & $\begin{array}{l}-0.438 \\
(0.336)\end{array}$ & $\begin{array}{l}-0.397 \\
(0.361)\end{array}$ & $\begin{array}{l}-0.286 \\
(0.295)\end{array}$ & $\begin{array}{c}0.131 \\
(0.319)\end{array}$ & $\begin{array}{l}-0.068 \\
(0.170)\end{array}$ & $\begin{array}{l}-0.143 \\
(0.255)\end{array}$ & $\begin{array}{l}-0.344 \\
(0.381)\end{array}$ & $\begin{array}{l}-0.361 \\
(0.387)\end{array}$ \\
\hline English & $\begin{array}{l}-0.421 \\
(0.586)\end{array}$ & $\begin{array}{l}-0.510 \\
(0.723)\end{array}$ & $\begin{array}{l}-0.343 \\
(0.625)\end{array}$ & $\begin{array}{c}-0.496 \\
(0.594)\end{array}$ & $\begin{array}{l}-0.398 \\
(0.616)\end{array}$ & $\begin{array}{l}-0.206 \\
(0.593)\end{array}$ & $\begin{array}{l}-0.616 \\
(0.659)\end{array}$ & $\begin{array}{l}-0.700 \\
(0.727)\end{array}$ & $\begin{array}{l}-0.914 \\
(0.819)\end{array}$ & $\begin{array}{l}-0.355 \\
(0.541)\end{array}$ & $\begin{array}{l}-0.343 \\
(0.587)\end{array}$ \\
\hline SelfDirection & $\begin{array}{l}-0.187 \\
(0.173)\end{array}$ & & & & & & & & & & \\
\hline Power & & $\begin{array}{c}0.139 \\
(0.167)\end{array}$ & & & & & & & & & \\
\hline Universalism & & & $\begin{array}{l}-0.007 \\
(0.152)\end{array}$ & & & & & & & & \\
\hline Achievement & & & & $\begin{array}{c}0.335 \\
(0.211)\end{array}$ & & & & & & & \\
\hline Security & & & & & $\begin{array}{c}0.067 \\
(0.151)\end{array}$ & & & & & & \\
\hline Performance & & & & & & $\begin{array}{l}-0.162 \\
(0.170)\end{array}$ & & & & & \\
\hline Stimulation & & & & & & & $\begin{array}{l}0.416^{\star *} \\
(0.184)\end{array}$ & & & & \\
\hline Conformity & & & & & & & & $\begin{array}{c}-0.422^{* *} \\
(0.194)\end{array}$ & & & \\
\hline Tradition & & & & & & & & & $\begin{array}{l}-0.431 \\
(0.332)\end{array}$ & & \\
\hline Hedonism & & & & & & & & & & $\begin{array}{c}0.109 \\
(0.102)\end{array}$ & \\
\hline Benevolence & & & & & & & & & & & $\begin{array}{c}0.157 \\
(0.215)\end{array}$ \\
\hline Constant & $\begin{array}{c}2.259 \\
(3.473)\end{array}$ & $\begin{array}{l}-1.650 \\
(3.067)\end{array}$ & $\begin{array}{l}-0.180 \\
(4.651)\end{array}$ & $\begin{array}{l}-4.895 \\
(3.572)\end{array}$ & $\begin{array}{l}-1.119 \\
(4.267)\end{array}$ & $\begin{array}{c}2.260 \\
(3.996)\end{array}$ & $\begin{array}{l}-4.123 \\
(2.759)\end{array}$ & $\begin{array}{c}1.633 \\
(3.246)\end{array}$ & $\begin{array}{c}3.417 \\
(4.774)\end{array}$ & $\begin{array}{l}-0.831 \\
(2.780)\end{array}$ & $\begin{array}{l}-1.666 \\
(3.682)\end{array}$ \\
\hline Observations & 23 & 23 & 23 & 23 & 23 & 23 & 23 & 23 & 23 & 23 & 23 \\
\hline R-squared & 0.229 & 0.250 & 0.215 & 0.428 & 0.222 & 0.300 & 0.357 & 0.554 & 0.329 & 0.248 & 0.230 \\
\hline
\end{tabular}

Robust standard errors in parentheses; professional associations omitted due to collinearity ${ }^{* * *} p<0.01,{ }^{* *} p<0.05,{ }^{*} p<0.1$ 
Table 4: Commerce, Law and Management Faculty: Schwartz's values and postgraduate supervision productivity

\begin{tabular}{|c|c|c|c|c|c|c|c|c|c|c|}
\hline Forta & (1) & (2) & (3) & (4) & (5) & (6) & (7) & (8) & (9) & (10) \\
\hline ractors & superv & superv & superv & superv & superv & superv & superv & superv & superv & superv \\
\hline SatTeach & $\begin{array}{l}-0.238^{*} \\
(0.135)\end{array}$ & $\begin{array}{c}-0.193 \\
(0.167)\end{array}$ & $\begin{array}{l}-0.244 \\
(0.145)\end{array}$ & $\begin{array}{l}-0.224 \\
(0.143)\end{array}$ & $\begin{array}{l}-0.165 \\
(0.110)\end{array}$ & $\begin{array}{l}-0.219 \\
(0.136)\end{array}$ & $\begin{array}{l}-0.230 \\
(0.143)\end{array}$ & $\begin{array}{l}-0.230 \\
(0.152)\end{array}$ & $\begin{array}{l}-0.234^{*} \\
(0.132)\end{array}$ & $\begin{array}{l}-0.107 \\
(0.184)\end{array}$ \\
\hline SatAdmin & $\begin{array}{l}-0.142 \\
(0.096)\end{array}$ & $\begin{array}{l}-0.178^{*} \\
(0.092)\end{array}$ & $\begin{array}{l}-0.159^{\star} \\
(0.090)\end{array}$ & $\begin{array}{l}-0.163^{*} \\
(0.090)\end{array}$ & $\begin{array}{l}-0.112 \\
(0.084)\end{array}$ & $\begin{array}{l}-0.158^{*} \\
(0.090)\end{array}$ & $\begin{array}{l}-0.161^{*} \\
(0.094)\end{array}$ & $\begin{array}{l}-0.158^{*} \\
(0.092)\end{array}$ & $\begin{array}{l}-0.161^{*} \\
(0.088)\end{array}$ & $\begin{array}{l}-0.133 \\
(0.092)\end{array}$ \\
\hline SatRes & $\begin{array}{c}0.102 \\
(0.110)\end{array}$ & $\begin{array}{c}0.127 \\
(0.131)\end{array}$ & $\begin{array}{c}0.075 \\
(0.103)\end{array}$ & $\begin{array}{c}0.100 \\
(0.107)\end{array}$ & $\begin{array}{c}0.102 \\
(0.104)\end{array}$ & $\begin{array}{c}0.099 \\
(0.110)\end{array}$ & $\begin{array}{c}0.094 \\
(0.102)\end{array}$ & $\begin{array}{c}0.093 \\
(0.107)\end{array}$ & $\begin{array}{c}0.074 \\
(0.110)\end{array}$ & $\begin{array}{c}0.155 \\
(0.142)\end{array}$ \\
\hline Age & $\begin{array}{c}0.017 \\
(0.026)\end{array}$ & $\begin{array}{c}0.020 \\
(0.028)\end{array}$ & $\begin{array}{c}0.019 \\
(0.027)\end{array}$ & $\begin{array}{c}0.020 \\
(0.029)\end{array}$ & $\begin{array}{c}0.018 \\
(0.026)\end{array}$ & $\begin{array}{c}0.018 \\
(0.029)\end{array}$ & $\begin{array}{c}0.019 \\
(0.026)\end{array}$ & $\begin{array}{c}0.019 \\
(0.025)\end{array}$ & $\begin{array}{c}0.014 \\
(0.029)\end{array}$ & $\begin{array}{c}0.008 \\
(0.019)\end{array}$ \\
\hline Gender1male & $\begin{array}{l}-0.626^{*} \\
(0.346)\end{array}$ & $\begin{array}{l}-0.710^{*} \\
(0.387)\end{array}$ & $\begin{array}{l}-0.599^{*} \\
(0.329)\end{array}$ & $\begin{array}{l}-0.657^{*} \\
(0.366)\end{array}$ & $\begin{array}{l}-0.713^{*} \\
(0.381)\end{array}$ & $\begin{array}{l}-0.649^{*} \\
(0.354)\end{array}$ & $\begin{array}{l}-0.651^{*} \\
(0.349)\end{array}$ & $\begin{array}{l}-0.649^{*} \\
(0.354)\end{array}$ & $\begin{array}{l}-0.674^{*} \\
(0.355)\end{array}$ & $\begin{array}{l}-0.528 \\
(0.318)\end{array}$ \\
\hline Prof assoc & $\begin{array}{c}0.139 \\
(0.316)\end{array}$ & $\begin{array}{c}0.213 \\
(0.371)\end{array}$ & $\begin{array}{c}0.139 \\
(0.322)\end{array}$ & $\begin{array}{c}0.172 \\
(0.351)\end{array}$ & $\begin{array}{c}0.087 \\
(0.284)\end{array}$ & $\begin{array}{c}0.139 \\
(0.315)\end{array}$ & $\begin{array}{c}0.131 \\
(0.339)\end{array}$ & $\begin{array}{c}0.130 \\
(0.353)\end{array}$ & $\begin{array}{c}0.113 \\
(0.310)\end{array}$ & $\begin{array}{c}0.290 \\
(0.431)\end{array}$ \\
\hline Span control & $\begin{array}{c}0.114 \\
(0.078)\end{array}$ & $\begin{array}{c}0.121 \\
(0.080)\end{array}$ & $\begin{array}{c}0.111 \\
(0.074)\end{array}$ & $\begin{array}{c}0.106 \\
(0.073)\end{array}$ & $\begin{array}{c}0.117 \\
(0.076)\end{array}$ & $\begin{array}{c}0.110 \\
(0.076)\end{array}$ & $\begin{array}{c}0.109 \\
(0.078)\end{array}$ & $\begin{array}{c}0.108 \\
(0.082)\end{array}$ & $\begin{array}{c}0.101 \\
(0.081)\end{array}$ & $\begin{array}{c}0.125 \\
(0.085)\end{array}$ \\
\hline Dependents & $\begin{array}{c}0.100 \\
(0.170)\end{array}$ & $\begin{array}{c}0.121 \\
(0.150)\end{array}$ & $\begin{array}{c}0.108 \\
(0.164)\end{array}$ & $\begin{array}{c}0.105 \\
(0.174)\end{array}$ & $\begin{array}{c}0.152 \\
(0.152)\end{array}$ & $\begin{array}{c}0.113 \\
(0.159)\end{array}$ & $\begin{array}{c}0.113 \\
(0.154)\end{array}$ & $\begin{array}{c}0.112 \\
(0.158)\end{array}$ & $\begin{array}{c}0.124 \\
(0.168)\end{array}$ & $\begin{array}{c}0.125 \\
(0.145)\end{array}$ \\
\hline English & $\begin{array}{c}0.379 \\
(0.335)\end{array}$ & $\begin{array}{c}0.290 \\
(0.287)\end{array}$ & $\begin{array}{c}0.347 \\
(0.321)\end{array}$ & $\begin{array}{c}0.267 \\
(0.265)\end{array}$ & $\begin{array}{c}0.252 \\
(0.314)\end{array}$ & $\begin{array}{c}0.350 \\
(0.316)\end{array}$ & $\begin{array}{c}0.349 \\
(0.310)\end{array}$ & $\begin{array}{c}0.341 \\
(0.328)\end{array}$ & $\begin{array}{c}0.326 \\
(0.331)\end{array}$ & $\begin{array}{c}0.430 \\
(0.366)\end{array}$ \\
\hline SelfDirection & $\begin{array}{l}-0.064 \\
(0.085)\end{array}$ & & & & & & & & & \\
\hline Power & & $\begin{array}{c}0.079 \\
(0.120)\end{array}$ & & & & & & & & \\
\hline Universalism & & & $\begin{array}{c}0.054 \\
(0.060)\end{array}$ & & & & & & & \\
\hline Achievement & & & & $\begin{array}{c}0.043 \\
(0.111)\end{array}$ & & & & & & \\
\hline Security & & & & & $\begin{array}{l}-0.095 \\
(0.073)\end{array}$ & & & & & \\
\hline Stimulation & & & & & & $\begin{array}{l}-0.011 \\
(0.065)\end{array}$ & & & & \\
\hline Conformity & & & & & & & $\begin{array}{c}0.008 \\
(0.065)\end{array}$ & & & \\
\hline Tradition & & & & & & & & $\begin{array}{c}0.006 \\
(0.070)\end{array}$ & & \\
\hline Hedonism & & & & & & & & & $\begin{array}{l}-0.058 \\
(0.076)\end{array}$ & \\
\hline Benevolence & & & & & & & & & & $\begin{array}{l}-0.192 \\
(0.199)\end{array}$ \\
\hline Constant & $\begin{array}{c}1.335 \\
(1.410)\end{array}$ & $\begin{array}{l}-0.250 \\
(2.746)\end{array}$ & $\begin{array}{l}-0.000 \\
(1.689)\end{array}$ & $\begin{array}{c}0.227 \\
(2.471)\end{array}$ & $\begin{array}{c}1.140 \\
(1.557)\end{array}$ & $\begin{array}{c}0.710 \\
(1.688)\end{array}$ & $\begin{array}{c}0.616 \\
(1.457)\end{array}$ & $\begin{array}{c}0.617 \\
(1.468)\end{array}$ & $\begin{array}{c}1.466 \\
(2.224)\end{array}$ & $\begin{array}{c}1.826 \\
(1.410)\end{array}$ \\
\hline Observations & 48 & 48 & 48 & 48 & 48 & 48 & 48 & 48 & 48 & 48 \\
\hline R-squared & 0.295 & 0.302 & 0.296 & 0.295 & 0.317 & 0.290 & 0.290 & 0.290 & 0.298 & 0.325 \\
\hline
\end{tabular}


Table 5: Faculty of Health Sciences: Schwartz's values and postgraduate supervision productivity

\begin{tabular}{|c|c|c|c|c|c|c|c|c|c|c|}
\hline \multirow{2}{*}{ Factors } & (1) & (2) & (3) & (4) & (5) & (6) & (7) & (8) & (9) & (10) \\
\hline & superv & superv & superv & superv & superv & superv & superv & superv & superv & superv \\
\hline \multirow[t]{2}{*}{ SatTeach } & -0.410 & -0.169 & 0.402 & -0.483 & $-2.593^{*}$ & -0.240 & -0.375 & -0.080 & -0.052 & -0.235 \\
\hline & (1.129) & $(0.397)$ & (1.373) & (0.991) & (0.348) & (0.551) & $(0.893)$ & $(0.141)$ & $(0.061)$ & (1.068) \\
\hline \multirow[t]{2}{*}{ SatAdmin } & 0.380 & -0.013 & -0.127 & 0.419 & $1.641^{*}$ & 0.215 & 0.261 & 0.271 & -0.029 & 0.225 \\
\hline & $(0.739)$ & $(0.302)$ & $(0.893)$ & $(0.716)$ & $(0.204)$ & $(0.404)$ & $(0.725)$ & $(0.094)$ & $(0.042)$ & $(0.734)$ \\
\hline \multirow[t]{2}{*}{ SatRes } & 0.542 & -0.045 & -0.132 & 0.649 & $2.086^{*}$ & 0.339 & 0.365 & 0.252 & 0.068 & 0.387 \\
\hline & (1.157) & $(0.425)$ & $(1.253)$ & $(0.952)$ & $(0.252)$ & $(0.577)$ & $(1.080)$ & $(0.136)$ & $(0.059)$ & $(0.951)$ \\
\hline \multirow[t]{2}{*}{ Age } & -0.091 & -0.031 & 0.026 & -0.103 & $-0.506^{*}$ & -0.060 & -0.103 & -0.096 & 0.000 & -0.040 \\
\hline & $(0.197)$ & (0.079) & $(0.204)$ & $(0.180)$ & $(0.064)$ & $(0.093)$ & $(0.127)$ & $(0.027)$ & $(0.012)$ & $(0.220)$ \\
\hline \multirow[t]{2}{*}{ Gender1male } & -0.181 & 0.193 & 0.864 & -0.319 & -2.182 & -0.102 & -0.257 & 0.114 & -0.110 & 0.339 \\
\hline & $(1.432)$ & $(0.541)$ & $(1.743)$ & $(1.331)$ & $(0.383)$ & $(0.787)$ & $(1.274)$ & $(0.196)$ & $(0.088)$ & (1.839) \\
\hline \multirow[t]{2}{*}{ Prof assoc } & 2.599 & -0.122 & -1.254 & 3.020 & $12.619^{*}$ & 1.662 & 1.819 & 0.655 & -0.220 & 1.754 \\
\hline & (5.918) & (2.319) & $(6.825)$ & $(5.193)$ & (1.612) & (2.935) & (5.385) & $(0.758)$ & $(0.331)$ & (5.263) \\
\hline \multirow[t]{2}{*}{ Span control } & -0.206 & 0.031 & 0.024 & -0.236 & $-0.971^{*}$ & -0.135 & -0.153 & -0.125 & 0.012 & -0.157 \\
\hline & $(0.409)$ & $(0.172)$ & $(0.430)$ & $(0.359)$ & $(0.121)$ & $(0.214)$ & $(0.362)$ & $(0.055)$ & $(0.025)$ & $(0.340)$ \\
\hline \multirow[t]{2}{*}{ Dependents } & 1.040 & -0.190 & -0.147 & 1.173 & $5.140^{*}$ & 0.622 & 0.852 & 0.814 & -0.120 & 0.613 \\
\hline & (1.995) & (0.973) & (2.112) & $(1.886)$ & (0.655) & (1.059) & $(1.644)$ & $(0.297)$ & $(0.137)$ & (2.077) \\
\hline \multirow{2}{*}{ English } & -0.356 & 0.040 & 0.204 & -0.428 & $-3.673^{*}$ & -0.209 & -0.273 & 0.012 & 0.059 & -0.078 \\
\hline & (1.167) & $(0.436)$ & (1.148) & $(0.880)$ & $(0.488)$ & $(0.603)$ & $(0.979)$ & $(0.161)$ & $(0.069)$ & (1.236) \\
\hline SelfDirection & $\begin{array}{c}0.062 \\
(0.254)\end{array}$ & & & & & & & & & \\
\hline Power & & $\begin{array}{c}0.231 \\
(0.080)\end{array}$ & & & & & & & & \\
\hline Universalism & & & $\begin{array}{c}0.119 \\
(0.151)\end{array}$ & & & & & & & \\
\hline Achievement & & & & $\begin{array}{l}-0.038 \\
(0.232)\end{array}$ & & & & & & \\
\hline Security & & & & & $\begin{array}{l}0.388^{\star} \\
(0.052)\end{array}$ & & & & & \\
\hline Stimulation & & & & & & $\begin{array}{c}0.096 \\
(0.090)\end{array}$ & & & & \\
\hline Conformity & & & & & & & $\begin{array}{c}0.111 \\
(0.217)\end{array}$ & & & \\
\hline Tradition & & & & & & & & $\begin{array}{l}0.262^{*} \\
(0.040)\end{array}$ & & \\
\hline Hedonism & & & & & & & & & $\begin{array}{l}0.150^{* *} \\
(0.008)\end{array}$ & \\
\hline Benevolence & & & & & & & & & & $\begin{array}{c}0.145 \\
(0.250)\end{array}$ \\
\hline \multirow[t]{2}{*}{ Constant } & -1.320 & 0.780 & -2.385 & -0.536 & 1.272 & -1.037 & 0.786 & -0.553 & -0.799 & -2.850 \\
\hline & $(4.330)$ & $(0.720)$ & (3.488) & (5.971) & $(0.607)$ & (2.529) & (5.694) & $(0.574)$ & $(0.229)$ & (4.653) \\
\hline Observations & 12 & 12 & 12 & 12 & 12 & 12 & 12 & 12 & 12 & 12 \\
\hline R-squared & 0.688 & 0.950 & 0.827 & 0.677 & 0.991 & 0.879 & 0.722 & 0.989 & 0.998 & 0.783 \\
\hline
\end{tabular}


Table 6: Faculty of Humanities: Schwartz's values and postgraduate supervision productivity

\begin{tabular}{|c|c|c|c|c|c|c|c|c|c|c|}
\hline \multirow{2}{*}{ Factors } & (1) & (2) & (3) & (4) & (5) & (6) & (7) & (8) & (9) & (10) \\
\hline & superv & superv & superv & superv & superv & superv & superv & superv & superv & superv \\
\hline \multirow[t]{2}{*}{ SatTeach } & -0.059 & -0.067 & -0.053 & -0.067 & -0.055 & -0.059 & -0.061 & -0.056 & -0.082 & -0.032 \\
\hline & $(0.054)$ & $(0.058)$ & $(0.055)$ & (0.059) & (0.055) & $(0.057)$ & $(0.058)$ & $(0.060)$ & $(0.061)$ & $(0.056)$ \\
\hline \multirow[t]{2}{*}{ SatAdmin } & 0.005 & -0.045 & -0.000 & -0.002 & -0.010 & -0.000 & -0.023 & 0.002 & 0.002 & 0.019 \\
\hline & $(0.070)$ & $(0.077)$ & (0.069) & $(0.070)$ & $(0.075)$ & $(0.070)$ & $(0.084)$ & $(0.079)$ & $(0.067)$ & $(0.068)$ \\
\hline \multirow[t]{2}{*}{ SatRes } & -0.032 & -0.016 & -0.022 & -0.020 & -0.023 & -0.019 & -0.019 & -0.023 & -0.038 & -0.026 \\
\hline & (0.089) & (0.089) & $(0.093)$ & $(0.090)$ & (0.094) & (0.091) & (0.091) & $(0.090)$ & $(0.094)$ & $(0.091)$ \\
\hline \multirow[t]{2}{*}{ Age } & 0.004 & 0.004 & 0.003 & 0.005 & 0.001 & 0.005 & 0.001 & 0.001 & 0.006 & 0.003 \\
\hline & (0.009) & (0.008) & $(0.009)$ & $(0.008)$ & (0.008) & $(0.010)$ & $(0.008)$ & $(0.008)$ & (0.008) & $(0.008)$ \\
\hline \multirow[t]{2}{*}{ Gender1male } & 0.063 & 0.086 & 0.059 & 0.110 & 0.087 & 0.039 & 0.055 & 0.065 & 0.043 & 0.033 \\
\hline & $(0.278)$ & $(0.278)$ & $(0.277)$ & $(0.299)$ & $(0.292)$ & $(0.263)$ & $(0.269)$ & $(0.276)$ & $(0.264)$ & $(0.268)$ \\
\hline \multirow[t]{2}{*}{ Prof assoc } & -0.092 & -0.189 & -0.139 & -0.192 & -0.099 & -0.147 & -0.137 & -0.114 & -0.251 & -0.099 \\
\hline & $(0.376)$ & $(0.378)$ & $(0.359)$ & $(0.404)$ & $(0.352)$ & $(0.377)$ & $(0.373)$ & $(0.375)$ & (0.399) & $(0.370)$ \\
\hline \multirow[t]{2}{*}{ Span control } & $0.041^{*}$ & $0.040^{*}$ & $0.043^{*}$ & $0.041^{*}$ & $0.042^{*}$ & $0.040^{*}$ & $0.043^{*}$ & $0.042^{*}$ & $0.041^{*}$ & $0.040^{*}$ \\
\hline & $(0.023)$ & $(0.022)$ & $(0.023)$ & $(0.022)$ & $(0.023)$ & $(0.022)$ & $(0.023)$ & $(0.023)$ & $(0.024)$ & $(0.022)$ \\
\hline \multirow[t]{2}{*}{ Dependents } & 0.079 & 0.040 & 0.062 & 0.065 & 0.076 & 0.088 & 0.063 & 0.073 & 0.091 & 0.059 \\
\hline & $(0.111)$ & (0.105) & $(0.115)$ & $(0.110)$ & $(0.115)$ & $(0.122)$ & $(0.108)$ & $(0.111)$ & $(0.116)$ & $(0.110)$ \\
\hline \multirow{2}{*}{ English } & 0.340 & $0.354^{*}$ & 0.308 & $0.350^{*}$ & $0.373^{*}$ & $0.368^{*}$ & $0.366^{*}$ & 0.317 & $0.423^{* *}$ & 0.289 \\
\hline & $(0.208)$ & $(0.198)$ & $(0.199)$ & $(0.196)$ & $(0.207)$ & $(0.190)$ & $(0.196)$ & $(0.197)$ & $(0.204)$ & $(0.196)$ \\
\hline SelfDirection & $\begin{array}{c}0.090 \\
(0.058)\end{array}$ & & & & & & & & & \\
\hline Power & & $\begin{array}{l}0.116^{\star *} \\
(0.047)\end{array}$ & & & & & & & & \\
\hline Universalism & & & $\begin{array}{l}-0.041 \\
(0.053)\end{array}$ & & & & & & & \\
\hline Achievement & & & & $\begin{array}{c}0.070 \\
(0.054)\end{array}$ & & & & & & \\
\hline Security & & & & & $\begin{array}{c}0.037 \\
(0.051)\end{array}$ & & & & & \\
\hline Stimulation & & & & & & $\begin{array}{c}0.057 \\
(0.060)\end{array}$ & & & & \\
\hline Conformity & & & & & & & $\begin{array}{c}0.050 \\
(0.054)\end{array}$ & & & \\
\hline Tradition & & & & & & & & $\begin{array}{l}-0.010 \\
(0.052)\end{array}$ & & \\
\hline Hedonism & & & & & & & & & $\begin{array}{l}0.110^{*} \\
(0.060)\end{array}$ & \\
\hline Benevolence & & & & & & & & & & $\begin{array}{l}-0.152^{\star *} \\
(0.066)\end{array}$ \\
\hline \multirow[t]{2}{*}{ Constant } & -0.282 & 0.043 & 1.312 & 0.036 & 0.375 & 0.111 & 0.446 & 0.827 & -0.022 & $2.074^{*}$ \\
\hline & (1.265) & $(0.775)$ & (1.065) & $(0.687)$ & $(0.782)$ & $(0.932)$ & (0.779) & $(0.748)$ & $(0.716)$ & (1.124) \\
\hline Observations & 103 & 103 & 103 & 103 & 103 & 103 & 103 & 102 & 103 & 103 \\
\hline R-squared & 0.134 & 0.159 & 0.126 & 0.138 & 0.126 & 0.132 & 0.129 & 0.121 & 0.172 & 0.156 \\
\hline
\end{tabular}


Table 7: Faculty of Science: Schwartz's values and postgraduate supervision productivity

\begin{tabular}{|c|c|c|c|c|c|c|c|c|c|c|}
\hline & (1) & (2) & (3) & (4) & (5) & (7) & (8) & (9) & (10) & (11) \\
\hline Factors & superv & superv & superv & superv & superv & superv & superv & superv & superv & superv \\
\hline SatTeach & $\begin{array}{l}-0.043 \\
(0.039)\end{array}$ & $\begin{array}{l}-0.041 \\
(0.039)\end{array}$ & $\begin{array}{c}-0.032 \\
(0.036)\end{array}$ & $\begin{array}{l}-0.043 \\
(0.037)\end{array}$ & $\begin{array}{l}-0.044 \\
(0.040)\end{array}$ & $\begin{array}{l}-0.042 \\
(0.039)\end{array}$ & $\begin{array}{l}-0.040 \\
(0.038)\end{array}$ & $\begin{array}{l}-0.043 \\
(0.039)\end{array}$ & $\begin{array}{l}-0.043 \\
(0.038)\end{array}$ & $\begin{array}{l}-0.015 \\
(0.051)\end{array}$ \\
\hline SatAdmin & $\begin{array}{c}0.041 \\
(0.047)\end{array}$ & $\begin{array}{c}0.037 \\
(0.045)\end{array}$ & $\begin{array}{c}0.041 \\
(0.043)\end{array}$ & $\begin{array}{c}0.047 \\
(0.048)\end{array}$ & $\begin{array}{c}0.037 \\
(0.045)\end{array}$ & $\begin{array}{c}0.041 \\
(0.048)\end{array}$ & $\begin{array}{c}0.042 \\
(0.049)\end{array}$ & $\begin{array}{c}0.041 \\
(0.051)\end{array}$ & $\begin{array}{c}0.043 \\
(0.049)\end{array}$ & $\begin{array}{c}0.032 \\
(0.046)\end{array}$ \\
\hline SatRes & $\begin{array}{c}-0.022 \\
(0.071)\end{array}$ & $\begin{array}{l}-0.028 \\
(0.070)\end{array}$ & $\begin{array}{l}-0.035 \\
(0.058)\end{array}$ & $\begin{array}{l}-0.020 \\
(0.072)\end{array}$ & $\begin{array}{l}-0.026 \\
(0.071)\end{array}$ & $\begin{array}{l}-0.022 \\
(0.071)\end{array}$ & $\begin{array}{l}-0.010 \\
(0.077)\end{array}$ & $\begin{array}{l}-0.022 \\
(0.075)\end{array}$ & $\begin{array}{l}-0.015 \\
(0.081)\end{array}$ & $\begin{array}{c}0.004 \\
(0.064)\end{array}$ \\
\hline Age & $\begin{array}{c}0.007 \\
(0.006)\end{array}$ & $\begin{array}{c}0.007 \\
(0.006)\end{array}$ & $\begin{array}{c}0.009 \\
(0.006)\end{array}$ & $\begin{array}{c}0.007 \\
(0.006)\end{array}$ & $\begin{array}{c}0.007 \\
(0.006)\end{array}$ & $\begin{array}{c}0.007 \\
(0.006)\end{array}$ & $\begin{array}{c}0.006 \\
(0.006)\end{array}$ & $\begin{array}{c}0.007 \\
(0.006)\end{array}$ & $\begin{array}{c}0.006 \\
(0.006)\end{array}$ & $\begin{array}{c}0.007 \\
(0.005)\end{array}$ \\
\hline Gender1male & $\begin{array}{c}0.362^{\star \star \star} \\
(0.123)\end{array}$ & $\begin{array}{l}0.378^{\star \star} \\
(0.136)\end{array}$ & $\begin{array}{c}0.457^{\star \star \star} \\
(0.137)\end{array}$ & $\begin{array}{c}0.359^{\star \star \star} \\
(0.127)\end{array}$ & $\begin{array}{c}0.357^{\star \star \star} \\
(0.120)\end{array}$ & $\begin{array}{c}0.367^{\star \star \star} \\
(0.127)\end{array}$ & $\begin{array}{l}0.345^{\star *} \\
(0.128)\end{array}$ & $\begin{array}{l}0.362^{* *} \\
(0.132)\end{array}$ & $\begin{array}{c}0.359^{\star \star \star} \\
(0.129)\end{array}$ & $\begin{array}{c}0.424^{\star \star \star} \\
(0.145)\end{array}$ \\
\hline Prof assoc & $\begin{array}{l}0.333^{*} \\
(0.190)\end{array}$ & $\begin{array}{l}0.341^{*} \\
(0.183)\end{array}$ & $\begin{array}{c}0.146 \\
(0.169)\end{array}$ & $\begin{array}{l}0.339^{*} \\
(0.190)\end{array}$ & $\begin{array}{l}0.327^{*} \\
(0.181)\end{array}$ & $\begin{array}{l}0.334^{*} \\
(0.186)\end{array}$ & $\begin{array}{l}0.323^{*} \\
(0.186)\end{array}$ & $\begin{array}{l}0.333^{*} \\
(0.193)\end{array}$ & $\begin{array}{l}0.311^{*} \\
(0.175)\end{array}$ & $\begin{array}{c}0.171 \\
(0.155)\end{array}$ \\
\hline Span control & $\begin{array}{l}-0.010 \\
(0.008)\end{array}$ & $\begin{array}{l}-0.010 \\
(0.008)\end{array}$ & $\begin{array}{l}-0.001 \\
(0.007)\end{array}$ & $\begin{array}{l}-0.010 \\
(0.008)\end{array}$ & $\begin{array}{l}-0.009 \\
(0.008)\end{array}$ & $\begin{array}{l}-0.009 \\
(0.009)\end{array}$ & $\begin{array}{l}-0.008 \\
(0.008)\end{array}$ & $\begin{array}{l}-0.010 \\
(0.009)\end{array}$ & $\begin{array}{l}-0.010 \\
(0.009)\end{array}$ & $\begin{array}{l}-0.001 \\
(0.007)\end{array}$ \\
\hline Dependents & $\begin{array}{l}-0.010 \\
(0.089)\end{array}$ & $\begin{array}{c}-0.006 \\
(0.090)\end{array}$ & $\begin{array}{l}-0.031 \\
(0.080)\end{array}$ & $\begin{array}{l}-0.018 \\
(0.091)\end{array}$ & $\begin{array}{l}-0.010 \\
(0.090)\end{array}$ & $\begin{array}{l}-0.011 \\
(0.087)\end{array}$ & $\begin{array}{c}-0.008 \\
(0.086)\end{array}$ & $\begin{array}{l}-0.010 \\
(0.095)\end{array}$ & $\begin{array}{l}-0.006 \\
(0.089)\end{array}$ & $\begin{array}{c}0.051 \\
(0.071)\end{array}$ \\
\hline English & $\begin{array}{c}-0.081 \\
(0.246)\end{array}$ & $\begin{array}{c}0.079 \\
(0.246)\end{array}$ & $\begin{array}{l}-0.020 \\
(0.192)\end{array}$ & $\begin{array}{l}-0.105 \\
(0.250)\end{array}$ & $\begin{array}{l}-0.076 \\
(0.241)\end{array}$ & $\begin{array}{l}-0.080 \\
(0.251)\end{array}$ & $\begin{array}{l}-0.091 \\
(0.241)\end{array}$ & $\begin{array}{l}-0.082 \\
(0.243)\end{array}$ & $\begin{array}{l}-0.079 \\
(0.239)\end{array}$ & $\begin{array}{c}0.042 \\
(0.217)\end{array}$ \\
\hline SelfDirection & $\begin{array}{c}0.002 \\
(0.040)\end{array}$ & & & & & & & & & \\
\hline Power & & $\begin{array}{c}0.021 \\
(0.037)\end{array}$ & & & & & & & & \\
\hline Universalism & & & $\begin{array}{l}0.078^{\star *} \\
(0.033)\end{array}$ & & & & & & & \\
\hline Achievement & & & & $\begin{array}{l}-0.026 \\
(0.027)\end{array}$ & & & & & & \\
\hline Security & & & & & $\begin{array}{c}0.004 \\
(0.027)\end{array}$ & & & & & \\
\hline Stimulation & & & & & & $\begin{array}{c}0.004 \\
(0.032)\end{array}$ & & & & \\
\hline Conformity & & & & & & & $\begin{array}{l}-0.020 \\
(0.029)\end{array}$ & & & \\
\hline Tradition & & & & & & & & $\begin{array}{c}0.001 \\
(0.031)\end{array}$ & & \\
\hline Hedonism & & & & & & & & & $\begin{array}{l}-0.013 \\
(0.033)\end{array}$ & \\
\hline Benevolence & & & & & & & & & & $\begin{array}{l}0.089^{* *} \\
(0.039)\end{array}$ \\
\hline Constant & $\begin{array}{l}-0.245 \\
(0.670)\end{array}$ & $\begin{array}{l}0.368 \\
(0.641)\end{array}$ & $\begin{array}{l}-1.386^{*} \\
(0.711)\end{array}$ & $\begin{array}{l}-0.012 \\
(0.643)\end{array}$ & $\begin{array}{l}-0.231 \\
(0.571)\end{array}$ & $\begin{array}{c}0.272 \\
(0.666)\end{array}$ & $\begin{array}{l}-0.123 \\
(0.575)\end{array}$ & $\begin{array}{l}-0.234 \\
(0.584)\end{array}$ & $\begin{array}{l}-0.169 \\
(0.564)\end{array}$ & $\begin{array}{l}-1.313^{*} \\
(0.657)\end{array}$ \\
\hline Observations & 37 & 37 & 37 & 37 & 37 & 37 & 37 & 37 & 37 & 37 \\
\hline R-squared & 0.321 & 0.326 & 0.438 & 0.331 & 0.322 & 0.322 & 0.333 & 0.321 & 0.325 & 0.410 \\
\hline
\end{tabular}


Over and above the influence of the control variables, in the full sample the full set of selfenhancement values, namely, power values, achievement values and hedonism values, are all significantly associated with postgraduate supervision throughput. Hypothesis A3 is not supported, in fact the opposite is found - that self-enhancement values are positively associated with supervision throughput, and not negatively. Whereas hedonism values relate to pleasure and enjoyment of life, achievement values relate to the achievement of success by demonstrating competence, ambition and influence (Schwartz 1996). Similarly, power values relate to social status, prestige, and "control or dominance over people and resources" (Schwartz 1996, 122). Although these self-enhancement values relate to the prioritisation of the self over others, they also relate to motivations that prioritise achievement, irrespective of the "selfish" motivations of this achievement behaviour.

Hypothesis A1, that openness to change values are positively and significantly associated with postgraduate supervision throughput, and Hypothesis A4, which relates to selftranscendence values, are not supported. These results run counter to the naïve expectation, supported by the descriptive statistics, that innovativeness (associated with openness to change values) and supportive caring (associated with self-transcendence values) would dominate in their contributions to postgraduate supervision throughput.

Hypothesis A2 is also not supported, in that if innovativeness were to drive postgraduate supervision throughput, then conservation values would be expected to be negatively associated, but they are not significant.

The finding that innovative values are not significantly associated with postgraduate supervision throughput seems to reflect a growing stream of literature that has identified a seeming lack of innovativeness in academic work (Callaghan, Callaghan and Jogee 2019) in scientific methodologies (Callaghan 2017; 2019), as well the failure of academic research to take up new opportunities offered by novel technologies (Rubin and Callaghan 2019).

These results are surprising and warrant further research in this context. If managerialist approaches borrowed from commercial contexts have taken root in academic contexts, then one might expect performance to be responsive to performance management systems, as those with self-interested values or non-innovative values might disproportionately respond to these incentives.

These results, however, do not take contextual conditions into account, and the analysis of the same relationships within the different faculty groups was expected to offer further more contextually specific insights. 


\section{Engineering}

Notwithstanding the small sample size, which makes testing excessively conservative, tests suggest that individuals in the (Faculty of Engineering and the Built Environment) FEBE faculty reflect one of the values tensions predicted by Schwartz (1994), between the innovative openness to change value type of stimulation, which is positively related to postgraduate supervision throughput, and the non-innovative conservation values type, conformity, which is negatively associated. It would seem that engineering-type supervision is sensitive to innovativeness (the primary difference between the openness to change and conservation types of values). The tension between self-oriented self-enhancement and self-transcendence values does not seem to be present.

\section{Commerce, Law and Management}

In contrast, FCLM respondents seem to exhibit little sensitivity to either of these tensions. This faculty, comprising the Schools of Accountancy, Business Administration, Economic and Business Sciences, Governance, and Law, may be the most diverse of the faculties however, and may therefore be more prone to heterogeneity bias. Most of these fields are professional in nature, with teaching and research relating to their specific fields.

\section{Health Sciences}

Tests of the Faculty of Health Sciences (FHS) sample reveal a positive but weak relationship between postgraduate supervision throughput in the health sciences and the non-innovative conservation values of tradition and security. A possible explanation might lie in the nature of healthcare work, in that safety protocols and established systems may take precedent over operational innovations in patient treatment. What is interesting, however, is the significance of the hedonism values item, suggesting that this self-enhancement values item coincides with conservation values in its contribution to postgraduate supervision throughput. Given that selfenhancement and conservation values are oppositional higher-order categories (Schwartz and Boehnke 2004), this finding suggests that health science might be a unique context in terms of values-driven postgraduate supervision throughput. Further research might look into this further.

\section{Humanities}

Power and hedonism values are positively related to postgraduate supervision throughput for supervisors in the humanities but benevolence is negatively associated. These associations reflect the tensions predicted to exist between self-enhancement and self-transcendence values 
(Schwartz and Boehnke 2004). Whereas for engineering it is the innovation tension between openness to change and conservation values that is significant, for the humanities it is the selfenhancement versus the self-transcendence tension. Self-enhancement values may provide a performance-based advantage in a way that is not inherently related to the selflessness associated with benevolence and universalism. The performance-based advantages of selforiented behaviour may be producing postgraduate supervision throughput to a greater extent than the more caring and supportive behaviours typically associated with benevolence values.

\section{Science}

Values associated with the prioritisation of the needs of others over the self are found to be positively related to postgraduate supervision throughput. Universalism and benevolence are positively and significantly associated with throughput but no other values items are significant. It would seem that the values of science supervision that are most conducive to throughput are those that one might typically expect in a university setting.

\section{Covariate influences}

In addition to providing insights into the potential influence of individual values on postgraduate supervision throughput, the results also show the effects of the covariates on postgraduate supervision after controlling for intrinsic influences associated with an individual's motivational values. In the full sample (Table 2), when the effects of power and conformity values are included, the coefficient of the satisfaction with administration term becomes negative and weakly significant. In the commerce faculty model (Table 4), there is a weak and negative effect across almost all the tested models. Further research might investigate the relationships between Schwartz's values and satisfaction with administration, particularly for fields that fall into the commerce faculty cluster. Although gender is not significant in the full sample, it is negative and significant in the commerce faculty cluster sample across almost all of the tested models. This suggests that men have significantly lower postgraduate supervision throughput than women in this cluster. This contrasts strongly with the science faculty sample, in which it is men who seem to have higher throughput according to all tested models. Interestingly, there is no significant effect for professional associations in the commerce faculty sample but there is in the science sample, where a weak positive effect seems to be present. Those with professional industry linkages in the sciences might have an advantage in supervision throughput in the sciences, more so than in other fields. In the full sample, span of control is weakly and positively significant across all the tested models. This effect seems to the driven by the humanities sample within it, as the same is true for humanities. It would seem 
that those in management positions in the humanities have significantly higher supervision throughput than those in other faculties - this may be evidence of managers leading by example. Having English as a home language seems to offer supervisors a throughput advantage in the humanities, as the majority of tested models are weakly and positively significant. Age and dependent children, however, do not seem to have an effect in the samples over and above the effects of values.

\section{CONCLUSIONS AND RECOMMENDATIONS FOR FURTHER RESEARCH}

The objective of the study was to empirically test theory that predicts that different individual value orientations of a supervisor may be differently associated with postgraduate supervision throughput.

The first overarching finding of the study seems to be the lack of support found for the expectation that innovative values would dominate in their contribution to postgraduate supervision throughout. This was given that innovativeness, in the form of openness to change values, is one of the four higher-order value types posited by Schwartz's values theory. It is only in engineering-related fields that innovative values seem to contribute to postgraduate supervision throughput.

A failure to respond innovatively to the needs of students may be particularly problematic in the South African context, one which is associated with a scarcity of resources. Further research should explore the relationships between innovative values and postgraduate supervision further in this context. To transform and be able to address problems, research into innovative values and their influence on university outcomes such as postgraduate supervision throughput might be useful.

The second main finding is that postgraduate supervision throughput is not primarily associated with caring values that prioritise the needs of others, but rather with those associated with achievement and the prioritisation of the needs of the self. This finding raises concerns about the extent to which performance management principles borrowed from the private business sector by university management might drive postgraduate supervision throughput. If so, it is possible that the values associated with these systems are being transferred to graduating students. A focus on the causal mechanisms that underlie this possibility are beyond the scope of this article, but future research is recommended to test whether this is occurring and, if so, what the consequences of this might be.

Further research might usefully explore the differences in the values associated with postgraduate supervision throughput between faculties. Fields associated with science seem to have the values expected of a university context in relation to higher postgraduate supervision 
throughput, such as benevolence and universalism. Further research should explore why other fields differ, as this might offer useful insights into how to improve throughput.

The conclusions of this study need to be considered in light of certain limitations of the work presented here. First, although individual values should be exogenous to postgraduate supervision throughput, certain of the covariates may not be. Future research should therefore seek to apply more sophisticated statistical methods than the OLS estimations applied here. Nevertheless, these results seem to be robust to covariate effects, as the covariates are only included to partial out covariate variance, and covariate effects are not interpreted causally. In fact, a contribution of the results may extend to the way they reveal correlations of certain antecedents of postgraduate supervision throughput that exist over and above an individual's motivational values.

Second, a limitation of this research is in its use of a single institution and the size of the sample. Although the sample size is sufficient to draw inferences about the tested relationships when the sample is pooled, the sample size decreases considerably when faculty-level subsamples are used. Nevertheless, interesting correlations are identified, given that these tests are conservative and they provide useful insights that complement those of the pooled sample. Future research might include multiple institutions to test whether the relationships found here may be generalised to other institutions in this context. Another related limitation of the study arises from the need to pool data so as to increase statistical power. Including masters and doctoral supervision in a single measure is therefore an important limitation, in that there may be differences between them. Nevertheless, what is given up in terms of an inability to model heterogeneity between masters and doctoral supervision is perhaps balanced by increased statistical power, in that the results represent shared variance associated with these levels of supervision. Further research should build on the findings here to explore these differences.

Notwithstanding these limitations, the study seems to provide important insights that could spur further research and, in addition, the results here highlight certain issues which may be of importance for those engaged in postgraduate degree supervision.

\section{REFERENCES}

Albertyn, R. M., P. Machika and C. Troskie-de Bruin. 2016. Towards responsible massification: Some pointers for supporting lecturers. Africa Education Review 13(3/4): 49-64.

Arvey, R. D., T. J. Bouchard, N. L. Segal and L. M. Abraham. 1989. Job satisfaction: Environmental and genetic components. Journal of Applied Psychology 74(2): 187-192.

Bitzer, E. M. and R. Albertyn. 2011. Alternative approaches to postgraduate supervision: A planning tool to facilitate supervisory processes. South African Journal of Higher Education 25(5): 875888.

Bitzer, E. and E. de Jager. 2018. The views of commerce students regarding "free" higher education in 
South Africa. South African Journal of Higher Education 32(4): 12-36.

Callaghan, C. W. 2017. Scientific real-time research problem solving and pharmaceutical innovation. African Journal of Science, Technology, Innovation and Development 9(4): 425-435.

Callaghan, C. W. 2018. Doctoral and masters supervision: Does preference for research versus teaching really make a difference? South African Journal of Higher Education 32(2): 43-64.

Callaghan, C. W. 2019. Business research methodologies and the need for economies of scale in the business research process: Harnessing the innovation opportunities of novel technologies and technological change. Electronic Journal of Business Research Methods 17(3): 179-190.

Callaghan, C. W., N. C. Callaghan and R. Jogee. 2019. Inequality in healthcare R\&D outcomes: A model of process disruption. Development Southern Africa. doi:10.1080/0376835X.2019.1649117

Callaghan, C. W. and D. A. L. Coldwell. 2014. Research versus teaching satisfaction and research productivity. International Journal of Educational Sciences 7(1): 203-218.

Campbell, D. T. and D. W. Fiske. 1959. Convergent and discriminant validation by the multitraitmultimethod matrix. Psychological Bulletin 56: 81-105.

Cascio, W. F. and H. Aguinis. 2011. Applied psychology in human resource management. New Jersey: Pearson.

Coldwell, D., E. Papageorgiou, C. W. Callaghan and A. Fried. 2016. Academic citizenship and wellbeing: An exploratory cross-cultural study of South African and Swedish academic perceptions. South African Journal of Higher Education 30(1): 80-105.

Data Database. 2011. ESS Human Values Scale/Portrait Values Questionnaire. http://datadatabase. files.wordpress.com/2011/03/schwartz-value-inventory.pdf (Accessed 12 July 2012).

Downie, R. S. 1980. Words. Journal of Medical Ethics 6: 33-34.

Duffy, R. D. 2010. Spirituality, religion and work values. Journal of Psychology and Theology 38(1): $52-61$.

Hodza, F. 2007. Managing the student-supervisor relationship for successful postgraduate supervision: A sociological perspective. South African Journal of Higher Education 21(8): 1155-1165.

Hofstede, G. 1980. Cultures consequences: International differences in work-related values. SAGE, Beverly Hills, CA.

House, R. J., P. J. Hanges, M. Javidan, P. W. Dorfman and V. Gupta. (Ed.). 2004. Culture, leadership and organizations: The GLOBE study of 62 societies. SAGE, Thousand Oaks, CA.

Humphrey, C. 2013. A paradigmatic map of professional education research. Social Work Education 32(1): 3-16.

Jogee, R., N. C. Callaghan and C. W. Callaghan. 2018. Student acculturation in the context of "FeesMustFall". South African Journal of Higher Education 32(2): 122-142.

Keane, M. 2016. Coaching interventions for postgraduate supervision courses: Promoting equity and understanding in the supervisor-student relationship. South African Journal of Higher Education 30(6): 94-111.

Manidis, M. 2016. Review of intercultural postgraduate supervision: Reimagining time, place and knowledge. Studies in Continuing Education 38(1): 126-127.

Manyike, T. V. 2017. Postgraduate supervision at an open distance e-learning institution in South Africa. South African Journal of Education 37(2): 1-11.

Maor, D. and J. Currie. 2017. The use of technology in postgraduate supervision pedagogy in two Australian universities. International Journal of Educational Technology in Higher Education 14(1): $1-15$.

Mouton, J. 2016. The Doctorate in South Africa. Trends, challenges and constraints. In Postgraduate supervision - Future foci for the knowledge society, ed. M. Fourie-Malherbe, C. Aitchison, E. Bitzer and R. Albertyn, 51-82. Stellenbosch: SUN Press.

Ngulube, P. and S. C. Ukwoma. 2019. Cartographies of research designs in library information science 
research in Nigeria and South Africa. Library \& Information Science Research 41(3): 100966.

Popper, K. R. 1963. Science as falsification. Conjectures and Refutations 1: 33-39.

Rambe, P. and M. Mkono. 2019. Appropriating WhatsApp-mediated postgraduate supervision to negotiate "relational authenticity" in resource-constrained environments. British Journal of Educational Technology 50(2): 702-734.

Rubin, A. and C. W. Callaghan. 2019. Entrepreneurial orientation, technological propensity and academic research productivity. Heliyon 5(8): e02328, 1-11.

Schwartz, S. H. 1992. Universals in the content and structure of values: Theory and empirical tests in 20 countries. In Advances in experimental and social psychology, vol. 25, ed. M. Zanna, 1-65. New York: Academic Press.

Schwartz, S. 1994. Are there universal aspects in the structure and contents of human values. Journal of Social Issues 50(4): 19-45. http://dx.doi.org/10.1111/j.1540-4560.1994.tb01196.x

Schwartz, S. 1996. Value priorities and behavior: Applying a theory of integrated value systems. http://www.palermo.edu/cienciassociales/publicaciones/pdf/Psico2/2Psico\%2007.pdf (Accessed 31 April 2012).

Schwartz, S. H. 2007. Chapter 7: A proposal for measuring orientations across nations. $\mathrm{http}$ ://www.europeansocialsurvey.org/index.php?option=com docmanandtask=doc viewandgid $=126$ andItemid $=80$ (Accessed 12 July 2012).

Schwartz, S. H. and K. Boehnke. 2004. Evaluating the structure of human values with confirmatory factor analysis. Journal of Research in Personality 38: 230-255. http://dx.doi.org/10.1016/S00926566(03)00069-2

Saroglou, V., V. Delpierre and R. Dernelle. 2004. Values and religiosity: A meta-analysis of studies using Schwartz's model. Personality and Individual Differences 37(4): 721-734.

Sinclair, M. 2004. Disciplinary investigation of PhD supervision. Australian Government Department of Education, Science and Training.

Stevens, S. S. 1946. On the theory of scales of measurement. Science 103(2684): 677-680.

Waghid, Y. 2006. Reclaiming freedom and friendship through postgraduate student supervision. South African Journal of Higher Education 11(4): 427-439.

Waghid, Y. and P. Smeyers. 2012. Reconsidering ubuntu: On the educational potential of a particular ethic of care. Educational Philosophy and Theory 44: 6-20.

Waghid, Y., Z. Waghid and F. Waghid. 2019. The Fourth Industrial Revolution reconsidered: On advancing cosmopolitan education. South African Journal of Higher Education 33(6): 1-9.

Wisker, G. and S. Claesson. 2013. The impact of cross-disciplinary culture on student-supervisor perceptions. International Journal of Doctoral Studies 8: 21-37. 